\title{
PENGARUH RETURN ON ASSET, RETURN ON EQUITY, DAN NET PROFIT MARGIN TERHADAP NILAI PERUSAHAAN BIDANG KONSTRUKSI YANG TERDAFTAR DI BURSA EFEK INDONESIA
}

\author{
* Tita Saraswati, Nurul Qomari, Indah Noviandari \\ Prodi Manajemen Fakultas Ekonomi dan Bisnis Universitas Bhayangkara, Indonesia
}

DOI: $10.46821 /$ benchmark.v1i1.19

\begin{abstract}
Abstrak
Nilai perusahaan merupakan nilai gabungan dari nilai pasar saham yang diterbitkan dan nilai pasar hutang dari suatu perusahaan dengan cara memaksimumkan nilai saham. Ada beberapa faktor yang dapat mempengaruhi nilai perusahaan antara lain: ROA (Return on Asset), ROE (Return on Equity), dan NPM (Net Profit Margin). Penelitian ini bertujuan untuk menguji pengaruh ROA (Return on Asset), ROE (Return on Equity), dan NPM (Net Profit Margin) terhadap nilai perusahaan (Tobin's q), analisis data pada penelitian ini menggunakan metode analisis regresi berganda untuk mengetahui pengaruh variabel-variabel yang terkait dalam penelitian. Hasil penelitian ini menunjukkan bahwa baik secara simultan maupun parsial ROA (Return on Asset), ROE (Return on Equity), dan NPM (Net Profit Margin) berpengaruh signifikan terhadap nilai perusahaan.

Kata Kunci: ROA, ROE, Nilai Prusahaan

Abstract

The value of the company is the combined value of the shares issued and the debt market value of a company by way of maximizing shareholder value. There are several factors that affect the value of the company include: ROA (Return on Asset), ROE (Return on Equity), dan NPM (Net Profit Margin). This study aimed to examine the effect of ROA (Return on Asset), ROE (Return on Equity), dan NPM (Net Profit Margin) on firm value (Tobin's q), in the analisys of the document, multiple regresiom analisys is used to determine the effect of the variables involved in this study. The results of this study indicate that both simultaneously and partially ROA (Return on Asset), ROE (Return on Equity), dan NPM (Net Profit Margin) significantly influence the value of the company.
\end{abstract}

Keywords: ROA, ROE, NPM, Comporate value

\section{PENDAHULUAN}

Pertumbuhan ekonomi Indonesia masih belum stabil, meskipun ada kenaikan yang didorong oleh meningkatnya permintaan domestik, terutama konsumsi, investasi non bangunan serta ekspor dan impor barang dan jasa. Sedangkan Investasi bangunan mengalami perlambatan didorong akibat masih lemahnya minat investasi.

Secara spasial, pertumbuhan ekonomi Indonesia di wilayah Kalimantan dan Kawasan Timur Indonesia masih melemah (Gambar 1), yang diakibatkan adanya kontraksi yang cukup dalam terjadi di Kalimantan Timur dan Papua. sementara perlambatan ekonomi di wilayah Kalimantan dipengaruhi oleh melambatnya seluruh sektor ekonomi, kecuali jasa keuangan.

*Corresponding Author:

Hal: $10-18$

Email: titasaraswati96@gmail.com 
Perkembangan perusahaan kostruksi Menurut observasi yang dilakukan oleh BUMN, ditemukan fakta bahwa pertumbuhan perusahaan bidang konstruksi diperkirakan dapat mencapai 10\% - 15\% seiring program Masterplan Percepatan dan Perluasan Pembangunan Ekonomi Indonesia (MP3EI) hingga tahun 2025. Potensi pasar konstruksi yang besar, ternyata belum optimal, karena hingga saat ini rata-rata pertumbuhan perusahaan bidang kostruksi tersebut pertahun mencapai 7\% - 8\%. Dari data tersebut maka dapat disimpulkan bahwa pertumbuhan perusahaan bidang konstruksi masih belum maksimal, salah satunya dikarenakan pangsa pasar masih dominan dikuasai oleh perusahaan konstruksi asing yang beroperasi di Indonesia seperti China Road and Bridge Corporation. Hal ini menunjukkan masih lemahnya daya saing perusahaan bidang konstruksi jika dibandingkan dengan perusahaan asing.

Berdasarkan kerangka konseptual (Gambar 2) maka dapat dikembangkan hipotesa penelitian sebagai berkut:

H1: Bahwa variabel Return on Asset, Return on Equity, dan Net Profit Margin secara simultan berpengaruh signifikan terhadap Nilai Perusahaan Bidang Konstruksi yang terdaftar di Bursa Efek Indonesia.

H2: Bahwa variabel Return on Asset, Return on Equity, dan Net Profit Margin secara parsial berpengaruh signifikan terhadap Nilai Perusahaan Bidang Konstruksi yang terdaftar di Bursa Efek Indonesia.

H3: Bahwa variabel Return on Equity yang berpengaruh dominan terhadap Nilai Perusahaan Bidang Konstruksi yang terdaftar di Bursa Efek Indonesia.

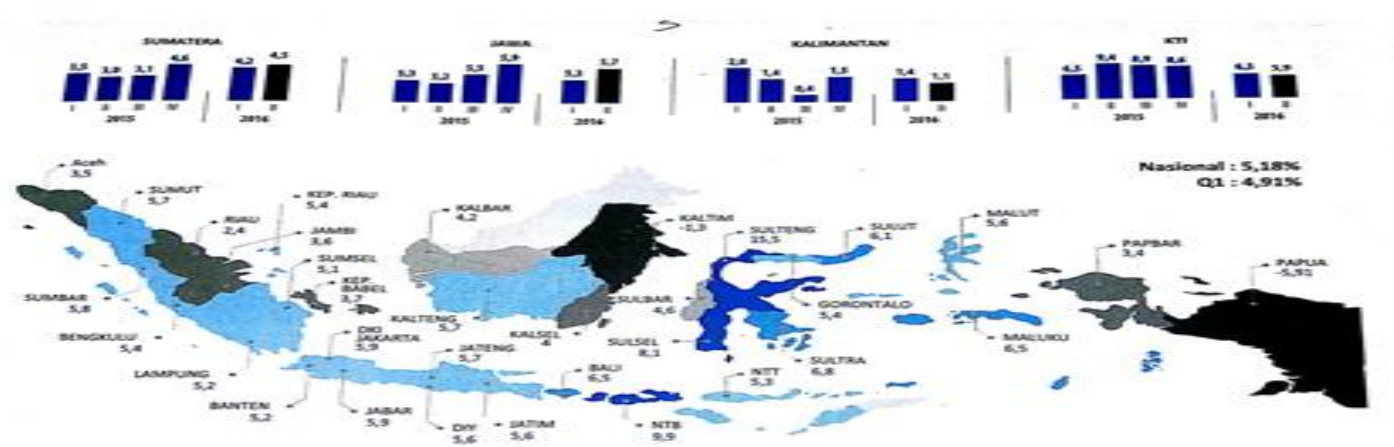

Sumber: Badan Pusat Statistik (Bank Indonesia, 2018: 07)

Gambar 1. Peta Pertumbuhan Ekonomi Daerah Triwulan II Tahun 2016

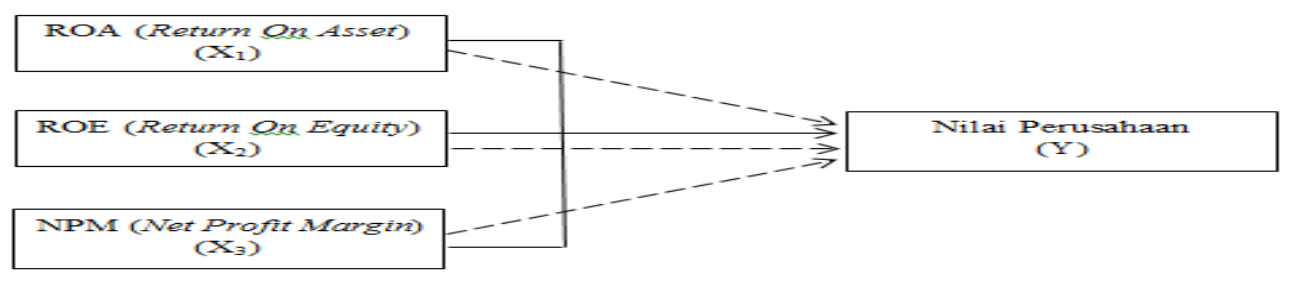

Sumber: Peneliti (2019)

Gambar 2. Kerangka Konseptual 


\section{METODE PENELITIAN}

Penelitian ini menggunakan dua jenis variabel, yaitu variabel bebas (X) dan variabel terikat (Y).

a. Variabel bebas $(\mathrm{X})$, merupakan variabel yang diduga mempengaruhi variabel terikat.

Variabel bebas yang digunakan dalam penelitian ini adalah:

1. ROA (Return on Asset) (X1)

Rasio ini mengukur kemampuan perusahaan untuk menghasilkan keuntungan atas Total Asset (Hery, 2016: 106). Untuk menghitung ROA digunakan rumus:

ROA (Return On Asset) $=\frac{\text { EAT (Earning After Tax) }}{\text { Total Altiva }}$

2. $\mathrm{ROE}$ (Return on Equity) (X2)

Rasio ini untuk mengukur kemampuan perusahaan dalam menghasilkan keuntungan dengan modal sendiri yang dimiliki (Hery, 2016: 107). Untuk menghitung ROE digunakan rumus:

ROE (Return On Equity) $=\frac{\text { EAT (Earning After Tax) }}{\text { Modal Sendiri }}$

3. NPM (Net Profit Margin) (X3)

Rasio ini untuk mengukur lemampuan perusahaan untuk menghasilkan keuntungan dibandingkan dengan penjualan yang dicapai (Sulindawati dkk, 2017: 141). Untuk menghitung NPM digunakan rumus:

NPM (Net Profit Margin) $=\frac{\text { Laba bersih setelah pajak }}{\text { Penjualan }}$

b. Variabel Terikat $(\mathrm{Y})$

Variabel terikat merupakan variabel yang dipengaruhi oleh variabel bebas. Variabel terikat dalam penelitian ini adalah nilai perusahaan dengan menggunakan analisis Tobin's Q. Analisis Tobin's Q menunjukkan tingkat kemakmuran pemegang saham (Prasetyorini,2013:04). Untuk menghitung Analisis Tobin's Q digunakan rumus:

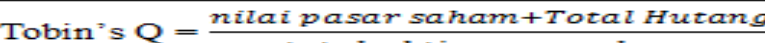
total aktiva perusahaan

Nilai pasar saham $=$ jumlah saham beredar $\mathrm{x}$ closing price

Populasi penelitian ini adalah perusahaan bidang konstruksi yang telah go public di Bursa Efek Indonesia, dengan menggunakan laporan keuangan interim periode $2017-$ 2018. Pemilihan sampel dilakukan dengan menggunakan purposive sampling, dengan kriteri-kriteria sebagai berikut:

a. Perusahaan yang masuk katagori perusahaan bidang konstruksi yang terdaftar di Bursa Efek Indonesia.

b. Emiten memiliki informasi mengenai perhitunggan nilai perusahaan, serta memiliki data rasio keuangan yang berkaitan dengan pengukuran variabel-variabel yang diperlukan. 
Analisis data dalam penelitian ini menggunakan metode regresi berganda untuk mengetahui bagaimana pengaruh variabel-variabel terkait.

\section{HASIL ANALISIS DAN PEMBAHASAN}

Berdasarkan perhitungan keseluruhan ROA (Return on Asset) pada periode 2017 ke periode 2018 mengalami kenaikan sebesar 39,64\%. Maka dapat disimpulkan bahwa hasil perhitungan rasio ini menunjukkan efektivitas dari manajemen dalam menghasilkan keuntungan yang berkaitan dengan ketersediaan asset perusahaan (Tabel 1).

Berdasarkan perhitungan keseluruhan ROE (Return on Equity) pada periode 2017 ke periode 2018 mengalami penurunan sebesar 35,32\%. Maka dapat disimpulkan bahwa perusahaan kurang dapat mengelola modal sendiri yang meningkat, sehingga laba yang diperoleh perusahaan menurun bila dibandingkan dengan jumlah modal sendiri yang semakin meningkat (Tabel 2).

Berdasarkan perhitungan keseluruhan NPM (Net Profit Margin) pada periode 2017 ke periode 2018 mengalami kenaikan sebesar 9,45\%. Maka dapat disimpulkan bahwa efektivitas dari manajemen dalam menghasilkan keuntungan yang berkaitan dengan tingkat penjualan perusahaan cukup baik (Tabel 3).

Berdasarkan perhitungan keseluruhan Nilai Perusahaan (Tobin's Q) pada periode 2017 ke periode 2018 mengalami penurunan sebesar 21,3\%. Maka dapat disimpulkan bahwa nilai pasar saham perusahaan menurun yang diakibatkan oleh faktor intenal ataupun faktor eksternal perusahaan (Tabel 4).

Tabel 1

\section{Hasil ROA (Return on Asset)}

\begin{tabular}{|l|c|c|c|c|c|r|r|}
\hline \multirow{2}{*}{ Perusahaan } & \multicolumn{3}{|c|}{ Tahun 2017 } & \multicolumn{3}{|c|}{ Tahun 2018 } & Rata-rata \\
\cline { 2 - 7 } & $\begin{array}{c}\text { Triwulan } \\
\text { I }\end{array}$ & $\begin{array}{c}\text { Triwulan } \\
\text { II }\end{array}$ & $\begin{array}{c}\text { Triwulan } \\
\text { III }\end{array}$ & $\begin{array}{c}\text { Triwulan } \\
\text { I }\end{array}$ & $\begin{array}{c}\text { Triwulan } \\
\text { II }\end{array}$ & $\begin{array}{c}\text { Triwulan } \\
\text { III }\end{array}$ & \\
\hline ADHI & 0,00097 & 0,00570 & 0,00841 & 0,00269 & 0,00804 & 0,01186 & 0,00628 \\
\hline WIKA & 0,00809 & 0,01328 & 0,01905 & 0,00429 & 0,01170 & 0,01859 & 0,01250 \\
\hline WSKT & 0,00657 & 0,01879 & 0,03313 & 0,01561 & 0,33489 & 0,34773 & 0,12612 \\
\hline PTPP & 0,00535 & 0,02050 & 0,31336 & 0,00463 & 0,01412 & 0,02273 & 0,06345 \\
\hline WTON & 0,01023 & 0,02317 & 0,03368 & 0,00810 & 0,02171 & 0,03600 & 0,02215 \\
\hline JUMIIAH & 0,03121 & 0,08144 & 0,40763 & 0,03532 & 0,39046 & 0,43691 & \\
\hline MEAN & 0,006242 & 0,016288 & 0,081526 & 0,007064 & 0,078092 & 0,087382 & \\
\hline
\end{tabular}

Sumber: Peneliti (2019)

Tabel 2

Hasil ROE (Return on Equity)

\begin{tabular}{|c|c|c|c|c|c|c|c|}
\hline \multirow[t]{2}{*}{ Perusahaan } & \multicolumn{3}{|c|}{ Tahum 2017} & \multicolumn{3}{|c|}{ Tahun 2018} & \multirow{2}{*}{ Rata-rata } \\
\hline & $\begin{array}{c}\text { Triwulan } \\
\text { I }\end{array}$ & $\begin{array}{c}\text { Triwulan } \\
\text { II }\end{array}$ & $\begin{array}{c}\text { Triwulan } \\
\text { III }\end{array}$ & $\begin{array}{c}\text { Triwulan } \\
\text { I }\end{array}$ & $\begin{array}{c}\text { Triwulan } \\
\text { II }\end{array}$ & $\begin{array}{l}\text { Triwulan } \\
\text { III }\end{array}$ & \\
\hline ADHI & 0,00359 & 0,02403 & 0,03702 & 0,01235 & 0,03582 & 0,05508 & 0,02798 \\
\hline WIKA & 0,02078 & 0,37848 & 0,05791 & 0,01461 & 0,04225 & 0,06871 & 0,09712 \\
\hline WSKT & 0,02225 & 0,06833 & 0,08867 & 0,07086 & 0,15010 & 0,16637 & 0,09443 \\
\hline PTPP & 0,01521 & 0,05396 & 0,31336 & 0,01328 & 0,04221 & 0,07240 & 0,08507 \\
\hline WTON & 0,02109 & 0,05428 & 0,08495 & 0,02133 & 0,05709 & 0,09539 & 0,05569 \\
\hline JUMIIAH & 0,08292 & 0,57908 & 0,58191 & 0,13243 & 0,32747 & 0,45795 & \\
\hline MEAN & 0,016584 & 0,115816 & 0,116382 & 0,026486 & 0,065494 & 0,09159 & \\
\hline
\end{tabular}

Sumber: Peneliti (2019) 
Tabel 3

Hasil NPM (Net Profit Margin)

\begin{tabular}{|l|c|c|c|c|c|c|c|}
\hline \multirow{2}{*}{ Perusahaan } & \multicolumn{3}{|c|}{ Tahun 2017 } & \multicolumn{3}{c|}{ Tahun 2018 } \\
\cline { 2 - 8 } & $\begin{array}{c}\text { Triwulan } \\
\text { I }\end{array}$ & $\begin{array}{c}\text { Triwulan } \\
\text { II }\end{array}$ & $\begin{array}{c}\text { Triwulan } \\
\text { III }\end{array}$ & $\begin{array}{c}\text { Triwulan } \\
\text { I }\end{array}$ & $\begin{array}{c}\text { Triwulan } \\
\text { II }\end{array}$ & $\begin{array}{c}\text { Triwulan } \\
\text { III }\end{array}$ & $\begin{array}{c}\text { Rata } \\
\text { ADHI }\end{array}$ \\
\hline W,00855 & 0,06022 & 0,02357 & 0,02335 & 0,03503 & 0,03564 & 0,03106 \\
\hline WIKA & 0,06954 & 0,05130 & 0,04806 & 0,03443 & 0,04874 & 0,05033 & 0,05040 \\
\hline WSKT & 0,06297 & 0,09173 & 0,10181 & 0,14000 & 0,17198 & 0,12404 & 0,11542 \\
\hline PTPP & 0,05527 & 0,07776 & 0,08050 & 0,05277 & 0,06542 & 0,07471 & 0,06774 \\
\hline WTON & 0,07117 & 0,06917 & 0,06520 & 0,04833 & 0,06174 & 0,06798 & 0,06339 \\
\hline JUMI_AH & 0,26745 & 0,35018 & 0,31914 & 0,29888 & 0,38291 & 0,35270 & \\
\hline MEAN & 0,05349 & 0,070036 & 0,063828 & 0,059776 & 0.076582 & 0,07054 & \\
\hline
\end{tabular}

Sumber: Peneliti (2019)

Tabel 4

Hasil Nilai Perusahaan (Tobin's Q)

\begin{tabular}{|c|c|c|c|c|c|c|c|}
\hline \multirow[t]{2}{*}{ Perusahaan } & \multicolumn{3}{|c|}{ Tahum 2017} & \multicolumn{3}{|c|}{ Tahun 2018} & \multirow[t]{2}{*}{ Rata-rata } \\
\hline & $\begin{array}{c}\text { Triwulan } \\
\text { I }\end{array}$ & $\begin{array}{l}\text { Triwulan } \\
\text { II }\end{array}$ & $\begin{array}{l}\text { Triwulan } \\
\text { III }\end{array}$ & $\begin{array}{c}\text { Triwulan } \\
\text { I }\end{array}$ & $\begin{array}{c}\text { Triwulan } \\
\text { II }\end{array}$ & $\begin{array}{c}\text { Triwulan } \\
\text { III }\end{array}$ & \\
\hline ADHI & 1,15569 & 1,09460 & 1,06433 & 1,05238 & 1,01604 & 0,95930 & 1,05706 \\
\hline WIKA & 1,27021 & 1,19019 & 1,07193 & 1,00670 & 0,94287 & 0,94480 & 1,07112 \\
\hline WASKITA & 1,17483 & 1,13992 & 1,02439 & 1,08128 & 0,99908 & 0,96956 & 1,06484 \\
\hline PTPP & 1,32804 & 1,24375 & 1,05172 & 1,03672 & 0,94626 & 0,88060 & 1,08118 \\
\hline WTON & 1,86385 & 1,47992 & 1,30669 & 1,25070 & 1,10144 & 1,03180 & 1,33896 \\
\hline JUMIAAH & 6,79262 & 6,14838 & 5,51906 & 5,42778 & 5,00569 & 4,78606 & \\
\hline MEAN & 1,358524 & 1,229676 & 1,103812 & 1,085556 & 1,001138 & 0,957212 & \\
\hline
\end{tabular}

Sumber: Peneliti (2019)

Tabel 5

Hasil Uji Multikolinaritas

\begin{tabular}{|l|l|l|l|}
\hline \multicolumn{2}{|c|}{ Model } & Tolerance & VIF \\
\hline \multirow{3}{*}{1.} & (Constant) & & \\
\cline { 2 - 4 } & $\mathrm{x} 1$ & .167 & -5980 \\
\cline { 2 - 4 } & $\mathrm{x} 2$ & -123 & 8.097 \\
\cline { 2 - 4 } & $\mathrm{x} 3$ & .407 & 2.459 \\
\hline
\end{tabular}

Sumber: Diolah Peneliti (2019)

\section{Analisis Hasil Penelitian}

\section{Asumsi Klasik}

a. Uji Normalitas: Hasil uji normalitas menghasilkan grafik Normal P-Plot yang memiliki titik-titik yang penyebaran datanya disekitar garis diagonal dan penyebarannya mengikuti arah garis diagonal. Hal ini dapat disimpulkan bahwa pola distribusi data mendekati normal.

b. Uji Multikolinaritas: Hasil pengujian Tolerance menunjukkan variabel bebas ROA (Return On Asset), ROE (Return On Equity) dan NPM (Net Profit Margin) tidak ada yang memiliki nilai tolerance kurang dari 0,10 (10\%). Hasil perhitungan VIF juga menunjukkan bahwa tidak ada satu variabel bebsa yang memiliki nilai VIF lebih dari 10, oleh karena itu dapat disimpulkan bahwa tidak ada multikolinieritas antara variabel dalam model regresi.

c. Uji Heterokedastisitas: Hasil Uji Heterokedastisitas menunjukkan bahwa penyebaran titik-titik secara acak, serta penyebaran titik-titik tersebut menyebar diatas dan dibawah angka 0 pada sumbu Y. Maka dapat disimpulkan bahwa tidak terjadi heterokedastisitas dalam persamaan ini, sehingga persamaan regresi ini layak dipakai untuk penelitian ini.

d. Uji Autokorelasi: Berdasarkan dari tabel 6 tersebut didapat nilai Durbin Watson dari model regresi sebesar 2,345 sedangkan dari tabel Durbin Watson dengan signifikasi 0,5 dan jumlah sampel $(\mathrm{n})=30$ serta $\mathrm{K}=3$ diperoleh dL sebesar 1,2138 dan dU sebesar 1,6498. Karena nilai Durbin Watson sebesar 2,445 berada pada daerah 
antara 4-dL $(4-1,2138)$ sebesar 2,7862 dan 4-dU (4 - 1,6498) sebesar 2,3502. Maka berdasarkan ketentuan $\mathrm{du}<\mathrm{d}<4-\mathrm{du}$ maka tidak ada autokorelasi positf ataupun negatif, maka tidak menghasilkan kesimpulan yang pasti (Tabel 6).

\section{Analisis Regresi Berganda}

Analisis ini digunakan untuk mengetahui variabel Return On Asset, Return On Equity dan Net Profit Margin berpengaruh terhadap Nilai Perusahaan dengan menggunakan persamaan berikut:

Berdasarkan Tabel 7, maka dapat disusun persamaan regresi linear berganda sebagai berikut:

$\mathrm{Y}=1.059+17.033 \mathrm{X}_{1}+7.755 \mathrm{X}_{2}+3.282 \mathrm{X}_{3}$

Maka dapat dijabarkan sebagai berikut:

a. Konstanta $\left(\beta_{0}\right)$ senilai 1.059 yang menunjukkan bahwa besarnya pengaruh variabel bebas terhadap variabel terikat, dimana apabila variabel bebas $=0$ maka nilai dari nilai perusahaan sebesar 1.059.

b. Nilai konstanta regresi variabel ROA $\left(\beta_{1}\right)$ sebesar 17.033 dengan arah positif menunjukkan bahwa ROA meningkat satu-satuan maka akan meningkatkan nilai perusahaan sebesar 17.033 satuan dengan asumsi variabel lain konstan.

c. Nilai konstanta regresi variabel $\operatorname{ROE}\left(\beta_{2}\right)$ sebesar 7.755 dengan arah positif menunjukkan bahwa ROE meningkat satu-satuan maka akan menurunkan nilai perusahaan sebesar 7.755 satuan dengan asumsi variabel lain konstan.

d. Nilai konstanta regresi variabel NPM $\left(\beta_{3}\right)$ sebesar 3.282 dengan arah positif menunjukkan bahwa NPM meningkat satu-satuan maka akan meningkatkan nilai perusahaan sebesar 3.282 satuan dengan asumsi variabel lain konstan.

Tabel 6

\section{Uji Autokorelasi}

\begin{tabular}{|c|c|c|c|c|c|}
\hline Model & $\mathbf{R}$ & R Square & $\begin{array}{c}\text { Adjusted R } \\
\text { Square }\end{array}$ & $\begin{array}{l}\text { Std. Error of } \\
\text { the Estimate }\end{array}$ & Durbin-Watson \\
\hline 1 & $.752=$ & .567 & .521 & .36550 & 2345 \\
\hline
\end{tabular}

Sumber: Diolah Peneliti (2019)

Tabel 7

Analisis Regresi Berganda

\begin{tabular}{|c|c|c|c|c|c|c|}
\hline \multirow{2}{*}{\multicolumn{2}{|c|}{ Model }} & \multicolumn{2}{|c|}{ Unstandardized Coefficients } & \multirow{3}{*}{$\begin{array}{c}\text { Standardized } \\
\text { Coefficients } \\
\text { Beta }\end{array}$} & \multirow{2}{*}{+} & \multirow[b]{2}{*}{ Sig. } \\
\hline & & B & Std. Error & & & \\
\hline \multirow[t]{4}{*}{1} & (Constant) & 1.059 & .069 & & 15.254 & .000 \\
\hline & ROA & 17.033 & 6.971 & .942 & 2.443 & .022 \\
\hline & ROE & 7.755 & 2.1 .44 & 1.622 & 3.616 & .001 \\
\hline & NPMI & 3.282 & 1.376 & 590 & 2.386 & .025 \\
\hline
\end{tabular}

Sumber: diolah peneliti (2019) 
Tabel 8

\begin{tabular}{|c|c|c|c|c|c|c|}
\hline & & Uji & $\begin{array}{l}\text { bel } 8 \\
\text { Simult }\end{array}$ & an) & & \\
\hline & & $\begin{array}{l}\text { Sum of } \\
\text { Squares }\end{array}$ & Df & Mean Square & $\mathrm{F}$ & Sig. \\
\hline 1 & Regression & 391 & 3 & .130 & 4.753 & $.009^{\circ}$ \\
\hline & Residual & .712 & 26 & .027 & & \\
\hline & Total & 1.103 & 29 & & & \\
\hline
\end{tabular}

Sumber: Diolah Peneliti (2019)

Tabel 9

Uji t (Parsial)

\begin{tabular}{|c|c|c|c|c|c|c|}
\hline & & \multicolumn{2}{|c|}{ Unstandardized Coefficients } & \multirow{2}{*}{$\begin{array}{l}\text { Standardized } \\
\text { Coefficients } \\
\text { Beta }\end{array}$} & \multirow[b]{2}{*}{ t } & \multirow[b]{2}{*}{ Sig. } \\
\hline \multicolumn{2}{|c|}{ Model } & B & Std. Error & & & \\
\hline \multirow[t]{4}{*}{1} & (Constant) & 1.059 & .069 & & 15.254 & .000 \\
\hline & ROA & 17.033 & 6.971 & .942 & 2.443 & .022 \\
\hline & ROE & 7.755 & 2.144 & 1.622 & 3.616 & .001 \\
\hline & NPM & 3.282 & 1.376 & .590 & 2.386 & .025 \\
\hline
\end{tabular}

Sumber: Diolah Peneliti (2019)

\section{Uji Simultan (Uji F)}

Uji ini menunjukkan apakah semua variabel bebas yang dimasukkan dalam model simultan mempunyai pengaruh secara bersama-sama terhadap variabel terikat (Wilona, 2018:74). Pengujian ini dilakukan dengan membandingkan nilai signifikansi $\mathrm{F}$ hitung dengan taraf signifikansi 0,05 (5\%).

Berdasarkan tabel diatas dapat diketahui bahwa nilai $\mathrm{F}$ hitung sebesar 4,753 sedangkan $\mathrm{F}$ tabel (dengan tingkat kepercayaan a sebesar 0,05 derajat bebas regresi sebesar 3 dan derajat residualnya 26) adalah sebesar 2,99 karena Fhitung lebih besar dari Ftabel maka $\mathrm{H}_{0}$ ditolak dan $\mathrm{H}_{1}$ diterima, dengan tingkat signifikan sebsar 0,009 lebih kecil dari 0,05. Sehingga dapat disimpulkan bahwa variabel bebas $\operatorname{ROA}\left(\mathrm{X}_{1}\right), \operatorname{ROE}\left(\mathrm{X}_{2}\right)$ dan NPM $\left(\mathrm{X}_{3}\right)$ secara simultan berpengaruh signifikan terhadap variabel terikatnya yaitu Nilai Perusahaan $(\mathrm{Y})$.

\section{Uji Parsial (Uji t)}

Pengujian ini bertujuan untuk menguji pengaruh variabel bebas terhadap variabel terikat.

Uji t dengan membandingkan $t_{\text {hitung }}$ dengan $t_{\text {tabel }}$.

Berdasarkan tabel diatas dapat diketahui bahwa:

a. Pengujian variabel ROA $\left(\mathrm{X}_{1}\right)$ : Pada Tabel diatas diperoleh $\beta_{\mathrm{ROA}}=17,033$, nilai $\mathrm{t}$ hitung $=2.443>\mathrm{t}$ tabel $=2,056$, serta nilai signifikan $0,022<5 \%(0,05)$. Maka dapat disimpulkan bahwa pengujian tersebut menunjukkan bahwa variabel ROA $\left(\mathrm{X}_{1}\right)$ secara parsial berpengaruh, bernilai positif signifikan terhadap variabel Nilai Perusahaan (Y).

b. Pengujian variabel $\operatorname{ROE}\left(\mathrm{X}_{2}\right)$ : Pada Tabel diatas diperoleh $\beta_{\mathrm{ROE}}=7,755$, nilai $\mathrm{t}$ hitung $=3,616>\mathrm{t}$ tabel $=2,056$, serta nilai signifikan $0,001<5 \%(0,05)$. Maka dapat disimpulkan bahwa pengujian tersebut menunjukkan bahwa variabel ROE 
$\left(\mathrm{X}_{2}\right)$ secara parsial berpengaruh, bernilai positif signifikan terhadap variabel Nilai Perusahaan (Y).

c. Pengujian variabel NPM $\left(\mathrm{X}_{3}\right)$ : Pada Tabel diatas diperoleh $\beta_{\mathrm{NPM}}=2,382$, nilai $\mathrm{t}$ hitung $=2,386>\mathrm{t}$ tabel $=2,056$, serta nilai signifikan $0,025<5 \%(0,05)$. Maka dapat disimpulkan bahwa pengujian tersebut menunjukkan bahwa variabel NPM $\left(\mathrm{X}_{3}\right)$ secara parsial berpengaruh, bernilai positif signifikan terhadap variabel Nilai Perusahaan $(\mathrm{Y})$.

\section{Pembahasan}

Pada umumnya tujuan suatu perusahaan adalah untuk meningkatkan kinerja perusahaan dalam menghadapi persaingan yang ketat tersebut, maka diperlukan suatu penanganan dan pengelolaan sumber daya yang dilakukan oleh pihak manajemen dengan baik.

1. Pengaruh Return On Asset, Return On Equity dan Net Profit Margin secara simultan berpengaruh signifikan terhadap Nilai Perusahaan.

Secara simultan dengan menggunakan uji F, diketahui $\mathrm{F}$ hitung sebesar 4,753 lebih besar dari $\mathrm{F}$ tabel sebesar 2,99 dengan tingkat signifikan sebesar 0,009 lebih kecil dari 0,05. Serta $\mathrm{R}$ square diperoleh sebesar 0,567 berarti 56,7\% variasi perubahan Nilai Perusahaan (Y) disebabkan oleh ROA (X1), ROE (X2) dan NPM (X3). Sedangkan sisanya 43,3\% variasi perubahan Nilai Perusahaan (Y) disebabkan oleh variabel-variabel lain yang tidak disertakan dalam penelitian ini.

2. Pengaruh Return On Asset, Return On Equity dan Net Profit Margin secara parsial berpengaruh signifikan terhadap Nilai Perusahaan.

Secara parsial dengan menggunakan uji t, diketahui bahwa untuk variabel ROA (X1) diketahui diperoleh $\beta$ ROA $=17,033$, nilai t hitung $=2.443>\mathrm{t}$ tabel $=2,056$, serta nilai signifikan $0,022<5 \%(0,05)$. Maka dapat disimpulkan bahwa pengujian tersebut menunjukkan bahwa variabel ROA (X1) secara parsial berpengaruh, bernilai positif signifikan terhadap variabel Nilai Perusahaan (Y). Hal ini mengindikasikan bahwa ROA memiliki pengaruh yang signifikan terhadap besar kecilnya Nilai Perusahaan untuk mengukur efektifitas laba bersih setelah pajak yang dihasilkan dalam perusahaan bidang konstruksi yang terdaftar di Bursa Efek Indonesia.

Secara parsial dengan menggunakan uji t, diketahui bahwa untuk variabel ROE (X2) diketahui $\beta \mathrm{ROE}=7,755$, nilai $\mathrm{t}$ hitung $=3,616>\mathrm{t}$ tabel $=2,056$, serta nilai signifikan $0,001<5 \%(0,05)$. Maka dapat disimpulkan bahwa pengujian tersebut menunjukkan bahwa variabel ROE (X2) secara parsial berpengaruh, bernilai positif signifikan terhadap variabel Nilai Perusahaan (Y). Hal ini mengindikasikan bahwa ROE memiliki pengaruh yang signifikan terhadap besar kecilnya Nilai Perusahaan untuk mengukur efektifitas laba bersih setelah pajak yang dihasilkan dalam perusahaan bidang konstruksi yang terdaftar di Bursa Efek Indonesia.

Secara parsial dengan menggunakan uji t, diketahui bahwa untuk variabel NPM (X3) diketahui $\beta \mathrm{NPM}=2,382$, nilai $\mathrm{t}$ hitung $=2,386>\mathrm{t}$ tabel $=2,056$, serta nilai signifikan $0,025<5 \%(0,05)$. Maka dapat disimpulkan bahwa pengujian tersebut menunjukkan bahwa variabel NPM (X3) secara parsial berpengaruh, bernilai positif signifikan terhadap variabel Nilai Perusahaan (Y). Hal ini mengindikasikan bahwa NPM memiliki pengaruh yang signifikan terhadap besar kecilnya Nilai Perusahaan 
untuk mengukur efektifitas laba bersih setelah pajak yang dihasilkan dalam perusahaan bidang konstruksi yang terdaftar di Bursa Efek Indonesia

3. Manakah diantara variabel Return On Asset, Return On Equity dan Net Profit Margin yang berpengaruh dominan terhadap Nilai Perusahaan

Berdasarkan Nilai standartdized of coefficient beta diantara variabel Return On Asset, Return On Equity dan Net Profit Margin yang memiliki nilai Beta tertinggi ialah Return On Equity, dengan nilai beta sebesar 1,622.

\section{SIMPULAN}

Simpulan penelitian ini adalah variabel Return On Asset, Return On Equity dan Net Profit Margin secara simultan berpengaruh signifikan terhadap Nilai Perusahaan. Sedangkan, variabel Return On Asset, Return On Equity dan Net Profit Margin secara parsial berpengaruh signifikan terhadap Nilai Perusahaan. Keterbatasan penelitian ini adalah dalam penelitian ini hanya menggunakan pengukuran rasio profitabilitas dan Nilai perusahaan (Analisis Tobin's Q) serta obyek yang diambil hanyalah perusahaan bidang konstruksi yang terdaftar di Bursa Efek Indonesia. Untuk penelitian selanjutnya sangat disarankan adanya penambahan rasio agar mampu mengukur Nilai Perusahaan dengan menggunakan rasio lainnya, dan perlu penambahan obyek penelitian dengan menambah jenis perusahaan lainnya, misalnya perusahaan manufaktur.

\section{DAFTAR PUSTAKA}

Bank Indonesia, Bank Central Republik Indonesia. (2018). Buletin Ekonomi Moneter Dan Perbankan.

Hery (2016). Analisis Kinerja Kenangan. Bumi Angkasa, Jakarta.

Prasetyorini, Bhekti Fitri. (2013). Pengaruh Ukuran Perusahaan, Leverage, PER, dan Profitabilitas Terhadap Nilai Perusahaan, Jurnal Uneversitas Negeri Surabaya.

Sukindawati, dkk. (2017). Manajemen Keuangan Sebagai Dasar Pengambilan Keputusan Bisnis, Rajagrafindo Persada, Depok.

Wilona, Brian Muda. (2018). Pengaruh Tingkat Perputaran Kas, Piutang, Persediaan Terhadap Rentabilitas Perusahaan Tekstil Yang Terdaftar di BEI, Skripsi, Universitas Bhayangkara, Surabaya 